\title{
Structural assimilation in young first-, second- and third-generation migrants in Flanders
}

\section{Floor Verhaeghe, Lieve Bradt, Mieke Van Houtte \& Ilse Derluyn}

To cite this article: Floor Verhaeghe, Lieve Bradt, Mieke Van Houtte \& Ilse Derluyn (2016): Structural assimilation in young first-, second- and third-generation migrants in Flanders, Ethnic and Racial Studies, DOI: 10.1080/01419870.2016.1260750

To link to this article: http://dx.doi.org/10.1080/01419870.2016.1260750

册 Published online: 01 Dec 2016.

Submit your article to this journal $₫$

山 Article views: 58

Q View related articles $₫$

View Crossmark data ¿ 


\title{
Structural assimilation in young first-, second- and third-generation migrants in Flanders
}

\author{
Floor Verhaeghe ${ }^{a}$, Lieve Bradt ${ }^{b}$, Mieke Van Houtte ${ }^{c}$ and Ilse Derluyn ${ }^{a}$ \\ ${ }^{a}$ Department of Social Work and Social Pedagogy, CESSMIR, Ghent University, Ghent, Belgium; \\ bepartment of Social Work and Social Pedagogy, Ghent University, Ghent, Belgium; \\ 'Department of Sociology, Research Group CuDOS, Ghent University, Ghent, Belgium
}

\begin{abstract}
Assimilation theory assumes that differences between migrants and nonmigrants disappear over generations. We report on a Flemish survey study conducted with young first- (G1), second- (G2) and third- (G3) generation migrants $(n=1,587)$. The results showed that $G 1$ and $G 2$ had lower chances of being in educational tracks preparing for higher education than non-migrants. Further, G1 and G3 migrants with a background in the oldest fifteen members of the European Union (EU15) and G1 and G2 adolescents of non-EU15 migrants ran a higher risk of being delayed in their educational trajectories. All three generations of non-EU15 migrants had lower expectations of finding a job than non-migrants. Whereas socio-economic status could explain almost all of the differences for EU15 migrants, it could not for non-EU15 migrants. This leads to the hypothesis that visible differences and distinctive names lead to assumptions about ethnic, cultural and religious affiliations that are associated with discrimination.
\end{abstract}

ARTICLE HISTORY Received 20 October 2015; Accepted 8 November 2016

KEYWORDS Structural assimilation; migrant generations; education; labour market; discrimination; multilevel analysis

\section{Introduction}

The processes taking place when people migrate from one country to another and try to settle have been studied through the lens of assimilation theory for almost a century (Park and Burgess 1969). Yet at the same time, the extensive discussion of these assimilation processes - often referred to as "integration" processes - points to the deep societal and political concerns that this topic arouses (Blommaert and Verschueren 1991). Assimilation has been a highly contested concept, but since its return in the 1990s as an analytical concept in the social sciences, more emphasis has been put on structural assimilation processes, in particular positions in educational systems and the labour market (Alba and Nee 1997). Furthermore, it is argued that assimilation is a 
process that occurs over several generations, rather than solely on an individual level (Brubaker 2001).

The central research question in this paper is whether we can find empirical evidence for such structural assimilation processes over generations. Our main hypothesis is that over several generations, the positions in education and the labour market of people with a migration background become gradually more equal to the positions of non-migrants. Current evidence in this field is rather mixed and incomplete (Alba and Nee 1997; Heath, Rothon, and Kilpi 2008), with, in particular, considerable intra-generational heterogeneity (Fincke 2008). This heterogeneity could be due to, first, the region of origin, which may impact on assimilation processes: non-Europeans, who are often non-whites and/or Muslims, are often confronted with more discriminatory and "othering" practices (Zemni 2011), making structural assimilation processes more difficult. Second, socio-economic status (SES) plays an important role: a lower SES background generally decreases opportunities in education and the labour market, yet it is unclear whether SES accounts for differences found between migrants and non-migrants or between generations (Kao and Thompson 2003). In examining possible associations between post-migration generations and educational attainment or occupational expectations, we will therefore control for SES background and differentiate for the region of origin. Data were collected among youngsters of three generations of migrants and among non-migrants.

\section{Background}

\section{Assimilation}

Assimilation is one of the most widely studied concepts used to examine the processes that take place when people migrate to another country and try to settle. Defined as "a process of interpenetration and fusion in which persons and groups acquire the memories, sentiments, and attitudes of other persons or groups, and [ ... ] are incorporated [ ... ] in a common cultural life" (Park and Burgess 1969, 735), the concept of assimilation has been in development since the 1920s, a peak period for migration to America (Brubaker 2001). However, more restrictive understandings of this concept, in particular its unidirectional interpretation, together with policies, such as Americanization in which people were pushed to take over the majority's identity and throw away their roots, have made assimilation a highly contested concept (Alba and Nee 1997).

After a differentialist turn in the 1980s and 1990s, when differences were celebrated, assimilation rapidly returned as a concept in the social sciences from the 1990s on, albeit in a transformed manner (Alba and Nee 1997). In mainstream newspapers and policy papers, the word "integration" has been 
used far more often (Blommaert and Verschueren 1991). "Integration" is, however, seldom explicitly defined and can implicitly often be boiled down to assimilation in its restrictive, unidirectional sense (Blommaert and Verschueren 1991). A first change in the concept as used in the social sciences was that, instead of ultimate, complete absorption, assimilation became regarded as a gradual change towards increasing similarity in some respects and between some groups (Alba and Nee 1997; Brubaker 2001). This implies that assimilation is not necessarily a unidirectional process, but that it can be bi- or multidirectional. Second, the normative concern in assimilation shifted from cultural to socio-economic themes (Alba and Nee 1997), in particular migrants' position in education and the labour market, which is also the focus of this paper. Third, assimilation is no longer seen as (solely) taking place at an individual level, but also as happening at a population level, over generations (Brubaker 2001). The idea of a straight-line assimilation theory, stating that each generation assimilates more until complete assimilation is reached, is often still maintained, but has been nuanced in the sense that it can be a "bumpy line", with interruptions and tangents at times (Alba and Nee 1997).

Additionally, the concept of "segmented assimilation" was introduced (Portes and Zhou 1993) as a second pathway, next to assimilation into the mainstream(s), that "leads straight into poverty and assimilation into the underclass", called "downward assimilation" (Portes and Zhou 1993, 82); and as a third pathway that "associates rapid economic advancement with deliberate preservation of the immigrant community's values and tight solidarity" (Portes and Zhou 1993, 82). Portes and Zhou (1993) further indicate that being of colour, living in marginalized neighbourhoods and being confronted with the absence of occupational mobility ladders are factors that render migrant children more vulnerable to downward assimilation.

\section{Generational differences}

There is evidence that young people with a migration background progress in their educational attainment over several generations. Based on German survey data, Fincke (2008) stated that migrants from the second generation attained higher educational levels than first-generation migrants. Phalet and Swyngedouw (2003) showed that there is progress from the first to the second generation of migrants in educational attainment, but that the overall gap compared with non-migrant members of the majority population remains significant.

Evidence regarding the labour market position of different generations of migrants is rather mixed. Fincke (2008) found that migrants from the second generation were doing better than those from the first generation, while 
Cheung (2014) did not find evidence for generational progress in the UK labour market: second-generation migrants continue to have a higher risk than majority population members of being unemployed or inactive, and those who have jobs earn less than majority population members, even when controlled for qualifications, language skills, age, marital status, citizenship status and the proportion of life spent in the UK.

\section{Intra-generational differences}

Given the intra-generational heterogeneity, in particular within the second generation, scholars have tried to identify factors that might explain these differences and also give insight into influences on inter-generational evolution. A first factor is the youngsters' region or country of origin: there is ample evidence that particular migrant groups (e.g. non-European migrants, who are often non-white and/or Muslims) are confronted with "othering" practices, making structural assimilation processes more difficult and enhancing feelings of not belonging (Portes, Fernández-Kelly, and Haller 2005; Silberman, Alba, and Fournier 2007). In their review of research on educational and labour market outcomes for second-generation migrants in ten Western European countries (including Belgium), Heath, Rothon, and Kilpi (2008) stated that "minorities whose parents came from less developed non-European origins tend to have substantially lower educational attainments or qualifications than do their respective majority groups" (p. 216). For Belgium, these most disadvantaged minority groups included people with a Turkish or Moroccan background. Minorities of European ancestry, for example, the Italians in Belgium, also had lower levels of attainment than the majority groups, but the minority-majority gap was somewhat smaller.

Second, migrants' SES exerts a large (negative) influence on their educational position. Research shows that overall a lower SES negatively impacts on educational trajectories and outcomes in the population (Breen and Jonsson 2005). Yet, whether SES flattens out all differences between people with and without a migration background remains unclear. In their review, Kao and Thompson (2003) showed that in some studies a significant difference between second-generation migrants and non-migrants persisted after controlling for SES, whereas in other research, this difference disappeared. Heath, Rothon, and Kilpi (2008) distinguished between secondgeneration groups of European ancestry and minorities from less developed countries: in the former group disadvantages could largely be explained by SES, while in the latter, significant differences remained after controlling for SES. Furthermore, research shows that a lower SES also impedes entrance into the labour market and the acquisition of high-ranked jobs (Breen and Jonsson 2005). SES seems thus to impact on chances in the labour market, 
yet other mechanisms disadvantaging people with a migrant background are also at stake (Heath, Rothon, and Kilpi 2008).

\section{Hypotheses}

Although there is already some understanding of inter-generational differences in migrants' positions in education and the labour market, questions still remain. First, most of the studies have focused on comparing migrants from the second generation with people without a migrant background (Heath, Rothon, and Kilpi 2008; Portes, Fernández-Kelly, and Haller 2005), without simultaneously considering differences between migrants from the first generation and people without a migrant background. Further, "second generation" is used as a broad category, including migrants with parents ("second generation") and grandparents ("third generation") born in another country (Cheung 2014). This implies that little is known about migrants from this third generation. This article therefore aims at further differentiating possible variations in structural assimilation (positions in education and the labour market) between non-migrants (G0) and youngsters with a migration background of the first (G1, born abroad), second (G2, at least one parent born abroad) and third generations (G3, at least one grandparent born abroad) (see Vlaams Economisch Sociaal Overlegcomité 2014). Flanders (the northern, Dutch-speaking part of Belgium) is an interesting research context, as the PISA results show that the gap between pupils with a migrant background (first and second generations) and non-migrant peers is, amongst all participating countries, the largest in Flanders (Jacobs et al. 2009). We hypothesize that the differences between $\mathrm{G0}$ on the one hand and G1-G2-G3 on the other will become smaller as generations move along and may eventually disappear, given the classical assimilation hypothesis (hypothesis 1). Second, we hypothesize that SES will have an overall impact on positions in education and the labour market, irrespective of the generation of the young migrants: adolescents with a lower SES will have lower positions in education and the labour market. The question is whether this effect of SES will be fully able to explain differences between the generations or whether the effect of generation still has explanatory power (hypothesis 2). The third hypothesis is that for non-EU15 migrants, the assimilation process over generations will evolve more slowly than for EU15 migrants (hypothesis 3). We operationalize the factor "region of origin" in this way because research shows that migrants coming from countries that joined the EU more recently (especially Eastern European countries) are constructed as "the other" and the majority of the members of the majority population are not in favour of migrants coming from Eastern Europe (Meuleman and Billiet 2003). EU15 refers to the fifteen member states of the European Union on 1 January 1995: Austria, Belgium, Denmark, Finland, France, Germany, Greece, Ireland, Italy, Luxembourg, the 
Netherlands, Portugal, Spain, Sweden and the UK (European Union 19952015).

\section{Context}

To fully comprehend and interpret the research results, we give below a brief overview of the Flemish education system and the measures taken - or not taken - in response to the presence of migrant children in Flemish schools.

The Flemish education system is composed of three chronological parts: three and a half years of non-compulsory education, six years of compulsory primary education and six years of compulsory secondary education, starting mostly at age twelve. In secondary education, youngsters can choose between four tracks: general, technical, vocational and artistic (the latter was not retained in this study, given the very limited number of pupils choosing this track). From age sixteen on, adolescents can enrol in a combined school and workplace track. While the choice of track is in principle free, teachers significantly influence this choice through their advice (Boone and Van Houtte 2013). Throughout secondary school, teachers can oblige pupils to repeat a year or exclude them from a certain track. Once enrolled in a track, moving to a "higher" track is difficult and rarely done, resulting in many pupils starting in the general track and then gradually "falling down" to the vocational track. Although, when successfully finished, all tracks lead to a certificate allowing pupils to access higher education, the general perception is that these tracks are hierarchically ranked (Boone and Van Houtte 2013): the general educational track is considered the most demanding, the vocational and combined school and workplace tracks have rather low esteem, and the technical track is situated in between (Boone and Van Houtte 2013).

When the first groups of labour migrants' children entered Flemish schools in the 1950 s, little special attention was paid to them. The government, as well as their parents, thought that their presence was only temporary and that they would eventually return to their home countries (Sierens 2006). In the 1970s and 1980s, it became clear that these migrants would stay. Nevertheless, no structural measures were taken, because the causes of the problems migrant children had at school were situated at home and in the neighbourhood rather than in the school (system) (Sierens 2006). Since 1991, more coherent plans were set up that also considered the responsibility of the school system (Sierens 2006).

\section{Methods}

\section{Procedure}

Students of eight secondary schools in two Belgian cities, Genk and SintNiklaas (four schools in each city), participated. These two cities were 
chosen since a large number of their inhabitants are migrants and migrant descendants: in Genk, 54.0 per cent of the inhabitants are of foreign origin (the second highest percentage of all cities in Flanders) (Vanduynslager et al. 2013); in Sint-Niklaas, 20.4 per cent of the inhabitants are of foreign origin ("Lokale Inburgerings- en Integratiemonitor 2013. SintNiklaas." 2013). Inhabitants of foreign origin are defined here as inhabitants whose current or first nationality is not Belgian or who have at least one parent without Belgian nationality as their first nationality (Vanduynslager et al. 2013).

In each city, we contacted schools that offer the different educational tracks in the Flemish educational system, as well as schools that mostly attract girls and schools that mostly attract boys, in order to capture the full diversity of youngsters in the Flemish educational system. Initially, nine schools were contacted, of which four did not wish to participate because they felt under too much pressure to participate in research. Three complementary schools were contacted, which all agreed to participate. All pupils in the fifth, sixth and, if available, seventh grades (in theory pupils between sixteen and nineteen years old) were asked to take part in the research. The researcher (i.e. the first author of this article) spent one to two weeks in each school to make sure that she could be present in every classroom when the survey was completed. In a classroom setting and during regular school hours, the researcher discussed the aim, content, informed consent forms and practicalities of the research with the pupils. The anonymity of the research was stressed and written informed consent was obtained from all respondents. The youngsters were given the opportunity to share their contact details with the researcher if they wished to receive information on the results of the research. They were given the contact details of the researcher, whom they could contact with further questions. Film tickets were raffled off as an incentive. All of the 1,628 adolescents present at school at the time of the data collection participated (Table 2).

Most participants completed an online survey during a fifty-minute period in the presence of the researcher and a teacher; 21 pupils completed the questionnaire on paper (due to a technical error), and 232 completed it without the researcher being present (due to planning problems in the schools), 69 on-line and 162 on paper.

In further analysis, the data of forty-one youngsters were not retained because they lived in the Netherlands $(n=18)$, because they were exchange students $(n=2)$ or because they did not complete all information on the birthplaces of their parents and grandparents $(n=21)$, which would have caused problems given the importance of these data for the research. 


\section{Variables}

\section{Independent variables}

Youngsters were asked about their own, their parents' and their grandparents' country of birth in order to group them into generations $(G 1, G 2, G 3, G 0$ coded from 1 to 4) and to distinguish between youngsters with EU15, non-EU15 and Belgian origin. When the youngster or one of his/her (grand)parents were born outside of the EU15, he/she was classified into the non-EU15 group (coded as $3, n=433 ; 27.3$ per cent). If the youngster or one of his/her (grand)parents were born in an EU15 country other than Belgium, he/she was classified into the EU15 group (2, $n=351 ; 22.1$ per cent). Members of the G0 group were all classified into a separate "Belgian" category $(1, n=803 ; 50.6$ per cent) (Tables 1 and 2).

For the SES of the participant's family, respondents were asked to fill in their parents' occupation, together with a small job description. The occupations were then classified into eight categories, based on the ten categories used in the International Standard Classification of Occupations (ISCO-08) developed by the International Labour Organization (International Labour Organization 2012). The category of "skilled agricultural, forestry and fishery workers" contained only a few cases $(n=9)$ and was merged with the category "craft and related trades workers". The category of "armed forces occupations" was not used: we chose to assign the few people in this category to the category that came closest to the actual occupation they were performing within the armed forces. Finally, non-working parents were classified in the category of "elementary occupations" (as in Bouverne-De Bie, Van de Walle, and Bradt 2014). In the ISCO-08, the highest SES is represented by the lowest number. We inverted this coding to make interpretation easier: SES ranges now from

Table 1. Distribution of ethnic origin by generation.

\begin{tabular}{|c|c|c|c|}
\hline & $\begin{array}{c}\mathrm{G} 1 \\
(n=150)\end{array}$ & $\begin{array}{c}\mathrm{G} 2 \\
(n=425)\end{array}$ & $\begin{array}{c}\mathrm{G} 3 \\
(n=209)\end{array}$ \\
\hline $\begin{array}{l}\text { EU15 } \\
(n=351)\end{array}$ & $\begin{array}{l}29 \text { Netherlands } \\
5 \text { Spain } \\
11 \text { others }\end{array}$ & $\begin{array}{l}34 \text { Italy - Belgium } \\
27 \text { Netherlands - Belgium } \\
22 \text { Italy } \\
17 \text { Germany - Belgium } \\
11 \text { Greece - Belgium } \\
8 \text { France - Belgium } \\
8 \text { Spain - Belgium } \\
19 \text { others }\end{array}$ & $\begin{array}{l}43 \text { Italy - Belgium } \\
30 \text { Netherlands - Belgium } \\
20 \text { Italy } \\
19 \text { Germany - Belgium } \\
11 \text { France - Belgium } \\
11 \text { Spain - Belgium } \\
26 \text { others }\end{array}$ \\
\hline $\begin{array}{l}\text { Non-EU15 } \\
(n=433)\end{array}$ & $\begin{array}{l}14 \text { Morocco } \\
14 \text { Turkey } \\
13 \text { Kosovo } \\
12 \text { Russia } \\
5 \text { India } \\
47 \text { others }\end{array}$ & $\begin{array}{l}80 \text { Turkey } \\
67 \text { Turkey - Belgium } \\
41 \text { Morocco } \\
31 \text { Morocco - Belgium } \\
6 \text { Poland - Belgium } \\
5 \text { Congo - Belgium } \\
49 \text { others }\end{array}$ & $\begin{array}{l}12 \text { Poland - Belgium } \\
6 \text { Morocco } \\
6 \text { Turkey } \\
25 \text { others }\end{array}$ \\
\hline
\end{tabular}

Note: ethnic origins group with at least $n=5$ were counted separately, the other were grouped into the "others' category". 
Table 2. Distribution of gender, age, socio-economic status and region of origin by generation ( $n(\%))$.

\begin{tabular}{|c|c|c|c|c|c|c|}
\hline & & $\begin{array}{c}\mathrm{G} 1 \\
(n=150)\end{array}$ & $\begin{array}{c}\mathrm{G} 2 \\
(n=425)\end{array}$ & $\begin{array}{c}\mathrm{G} 3 \\
(n=209)\end{array}$ & $\begin{array}{c}\mathrm{G} 0 \\
(n=803)\end{array}$ & $\begin{array}{l}\text { Total group } \\
(n=1,587)\end{array}$ \\
\hline \multirow{3}{*}{$\begin{array}{l}\text { Gender } \\
\quad(n=1,587) \\
\text { Age }^{\mathrm{a}} \\
\quad(n=1,587)\end{array}$} & Male & $108(72.0 \%)$ & $270(63.5 \%)$ & $134(64.1 \%)$ & $449(55.9 \%)$ & $961(60.6 \%)$ \\
\hline & Female & $42(28.0 \%)$ & $155(36.5 \%)$ & $75(35.9 \%)$ & $354(44.1 \%)$ & $626(39.4 \%)$ \\
\hline & & $19.03(1.39 ; 15-25)$ & $18.39(1.15,14-23)$ & $18.17(1.02 ; 16-21)$ & $18.04(0.95 ; 14-22)$ & $18.24(1.10,14-25)$ \\
\hline \multirow{8}{*}{$\begin{array}{l}\text { Socio-economic } \\
\text { status } \\
(n=1,575)\end{array}$} & Elementary occupations and non-working & $52(35.6 \%)$ & $110(26.0 \%)$ & $17(8.3 \%)$ & $64(8.0 \%)$ & $243(15.4 \%)$ \\
\hline & Plant and machine operators, and assemblers & $17(11.6 \%)$ & $52(12.3 \%)$ & 19 (9.3\%) & $53(6.6 \%)$ & $141(9.0 \%)$ \\
\hline & $\begin{array}{l}\text { Craft and related trades workers and skilled } \\
\text { agricultural, forestry and fishery workers }\end{array}$ & $30(20.5 \%)$ & $75(17.7 \%)$ & $26(12.7 \%)$ & $84(10.5 \%)$ & $215(13.7 \%)$ \\
\hline & Service and sales workers & $13(8.9 \%)$ & $50(11.8 \%)$ & $36(17.6 \%)$ & $103(12.9 \%)$ & $202(12.8 \%)$ \\
\hline & Clerical support workers & $7(4.8 \%)$ & $21(5.0 \%)$ & $17(8.3 \%)$ & $70(8.7 \%)$ & $115(7.3 \%)$ \\
\hline & Technicians and associate professionals & $12(8.2 \%)$ & $49(11.6 \%)$ & $33(16.1 \%)$ & $121(15.1 \%)$ & $215(13.7 \%)$ \\
\hline & Professionals & $6(4.1 \%)$ & $45(10.6 \%)$ & $32(15.6 \%)$ & $191(23.8 \%)$ & $274(17.4 \%)$ \\
\hline & Managers & $9(6.2 \%)$ & $21(5.0 \%)$ & $25(12.2 \%)$ & $115(14.4 \%)$ & $170(10.8 \%)$ \\
\hline \multirow{3}{*}{$\begin{array}{l}\text { Region of origin } \\
\quad(n=1,587)\end{array}$} & Belgium & 0 & 0 & 0 & $803(100 \%)$ & $803(50.6 \%)$ \\
\hline & EU15 & $45(30.0 \%)$ & $146(34.4 \%)$ & $160(76.6 \%)$ & 0 & $351(22.1 \%)$ \\
\hline & Non-EU15 & $105(70.0 \%)$ & $279(65.6 \%)$ & $49(23.4 \%)$ & 0 & $433(27.3 \%)$ \\
\hline
\end{tabular}

${ }^{\mathrm{a}}$ Mean (SD, range).

Elementary occupations and non-working

trachine operators, and assemblers

agricultural, forestry and fishery workers

Technicians and associate professionals

Belgium

Non-EU15

$105(70.0 \%)$

$279(65.6 \%)$

$49(23.4 \%)$

$433(27.3 \%)$ 
1 (elementary occupations and the non-working) to 8 (managers) (see Table 1). The family's SES was based on the category of the highest scoring parent. When there was only one parent or when information about one of the parents was missing, the information on the remaining parent was used $(n=115)$. If the information for both parents was missing, the family's SES was considered a missing value $(n=12)$.

We included gender as a control variable. In total, 961 boys (coded as 1, 60.6 per cent) and 626 girls (coded as 0, 39.4 per cent) participated. The large number of boys in the sample is mainly due to the inclusion of two large schools that almost exclusively attract boys because of the type of education they offer (e.g. mechanics and construction).

\section{Dependent variables}

Three dependent variables were included. First, the current educational track was included, namely the general, technical, vocational or combined school and workplace track. The answers were recoded into two categories: preparing for higher education (general and technical tracks (1) $(n=890 ; 56.1$ per cent) or not preparing for higher education (vocational and combined school and workplace tracks $(0)$ ( $n=695 ; 43.8$ per cent).

The second variable was whether or not the youngsters had a delay in their educational trajectories. The age of the pupils was compared to the age they should have been when in the fifth, sixth or seventh grade of secondary school in a regular educational trajectory. All pupils who were older than that regular age were considered as having been delayed in their educational trajectories, for example because of repeating a year (1) $(n=700 ; 44.2$ per cent). The others were considered as not having been delayed in their trajectories $(0)$ ( $n=885 ; 55.8$ per cent).

Third, we asked how certain the participants were they would find a job quickly after finishing their education. Answers were given on a fivepoint Likert scale, ranging from "very uncertain" (1) to "very certain" (5). 56 or 3.5 per cent of the youngsters answered they were very uncertain, 112 or 7.1 per cent were rather uncertain, 377 or 23.8 per cent were neither certain nor uncertain, 734 or 46.3 per cent were rather certain and 302 or 19.0 per cent were very certain. Those who answered they were "very uncertain", "rather uncertain" or "neither certain or uncertain" were also asked why they thought they would not find a job quickly. We indicated a couple of possible reasons and left it open to them to state a different one.

\section{Analysis}

Two-step multilevel regression analyses were executed to correct for the fact that the participants were nested within schools (Hox 2010). A first set of 
logistic regressions examined possible significant differences between the four generations in the educational tracks preparing for higher education on the one hand and not preparing for higher education on the other (G0G1-G2-G3) (hypothesis 1). The reference category was "not preparing for higher education". In a first step, generation was entered into the model while controlling for gender, since we know that a considerable gender gap exists when it comes to educational attainment (with boys, for example, obtaining lower grades and having fewer opportunities to enrol in higher education; see, for example, Vantieghem et al. 2014). In a second step, SES was added as an independent variable to detect whether the possible impact of generation was suppressed, magnified or not affected by SES (hypothesis 2). All analyses were performed separately for the EU15 group and the nonEU15 group, who were compared to non-migrants. These analyses enabled us to examine how the models differed according to the participants' region of origin (hypothesis 3). Similarly, a second set of logistic regressions was used to explore possible differences regarding delay in educational trajectories. The reference category was "no delay". A third similar set of linear regressions investigated possible differences in participants' expectations about the labour market.

\section{Results}

Bivariate analyses of educational track, delay in educational trajectory and certainty about finding a job after graduating by generation, gender, SES and region of origin (Table 3 ) already showed differences in educational track, delay in educational trajectory and expectations about finding a job after finishing school between generations (hypothesis 1), boys and girls, respondents with a high and low SES (hypothesis 2), and youngsters with a Belgian/EU15/ non-EU15 background (hypothesis 3). Migrants were underrepresented in educational tracks preparing for higher education and more migrants had a delay in their educational trajectories, although change did occur over generations. These results are in line with existing evidence on the first and second generations. Regarding expectations about opportunities in the labour market, differences seemed small at first sight, which is rather at odds with existing evidence.

Considering the differences between generations (hypothesis 1) within the EU15 group (hypothesis 3) (Table 4), we saw that G1 and G2 had lower chances of being in an educational track that prepares for higher education compared to G0, but that there was no significant difference between $\mathrm{G} 3$ and G0 (Table 4, model 1). Participants of the generations G1 and G3 more often showed a delay in their educational trajectories (Table 4, model 1). For none of the migrant generations was there a significant difference with G0 in the variable "to find a job quickly after graduation" (Table 4, model 5). 
Table 3. Distribution of educational track, delay in educational trajectory and certainty about finding a job after graduating by generation, gender, SES and region of origin.

\begin{tabular}{|c|c|c|c|c|c|c|}
\hline & & \multicolumn{2}{|c|}{$\begin{array}{l}\text { Educational track } \\
\qquad(n=1,585)\end{array}$} & \multicolumn{2}{|c|}{$\begin{array}{c}\text { Delay } \\
(n=1,585)\end{array}$} & \multirow[b]{2}{*}{$\begin{array}{c}\text { Job }^{\mathrm{a}} \\
(n=1,581)\end{array}$} \\
\hline & & $\begin{array}{l}\text { Not preparing for } \\
\text { higher education }\end{array}$ & $\begin{array}{l}\text { Preparing for } \\
\text { higher education }\end{array}$ & No delay & Delay & \\
\hline \multirow{4}{*}{$\begin{array}{l}\text { Generation } \\
\quad(n=1,587)\end{array}$} & $\mathrm{G} 1$ & $96(64.0 \%)$ & $54(36.0 \%)$ & $34(22.7 \%)$ & $116(77.3 \%)$ & $3.69(1.11)$ \\
\hline & $\mathrm{G} 2$ & $225(52.9 \%)$ & $199(46.8 \%)$ & $189(44.6 \%)$ & $235(55.4 \%)$ & $3.60(0.96)$ \\
\hline & G3 & $83(39.7 \%)$ & $125(59.8 \%)$ & $115(55.3 \%)$ & $93(44.7 \%)$ & $3.80(0.95)$ \\
\hline & G0 & $291(36.2 \%)$ & $512(63.8 \%)$ & $547(68.1 \%)$ & $256(31.9 \%)$ & $3.74(0.95)$ \\
\hline \multirow{2}{*}{$\begin{array}{l}\text { Gender } \\
\qquad(n=1,587)\end{array}$} & Boys & $516(53.8 \%)$ & $444(46.2 \%)$ & $479(49.9 \%)$ & $481(50.1 \%)$ & $3.88(0.96)$ \\
\hline & Girls & $179(28.6 \%)$ & $446(71.4 \%)$ & $406(65.0 \%)$ & $219(35.0 \%)$ & $3.43(0.93)$ \\
\hline \multirow{8}{*}{$\begin{array}{l}\text { SES } \\
\qquad(n=1,575)\end{array}$} & Elementary occupations and non-working & $159(65.4 \%)$ & $84(34.6 \%)$ & $84(34.6 \%)$ & $159(65.4 \%)$ & $3.55(1.00)$ \\
\hline & Plant and machine operators, and assemblers & $87(62.1 \%)$ & $53(37.9 \%)$ & $63(45.0 \%)$ & $77(55.0 \%)$ & $3.84(0.97)$ \\
\hline & $\begin{array}{l}\text { Craft and related trades workers and skilled agricultural, } \\
\text { forestry and fishery workers }\end{array}$ & $124(57.7 \%)$ & $91(42.3 \%)$ & $105(48.8 \%)$ & $110(51.2 \%)$ & $3.72(1.02)$ \\
\hline & Service and sales workers & $107(53.0 \%)$ & $95(47.0 \%)$ & $108(53.5 \%)$ & $94(46.5 \%)$ & $3.81(0.91)$ \\
\hline & Clerical support workers & $39(34.2 \%)$ & $75(65.8 \%)$ & $67(58.8 \%)$ & $47(41.2 \%)$ & $3.56(0.96)$ \\
\hline & Technicians and associate professionals & $83(38.6 \%)$ & $132(61.4 \%)$ & $126(58.6 \%)$ & 89 (41.4\%) & $3.75(1.03)$ \\
\hline & Professionals & $52(19.0 \%)$ & $222(81.0 \%)$ & $202(73.7 \%)$ & $72(26.3 \%)$ & $3.71(0.88)$ \\
\hline & Managers & $37(21.8 \%)$ & $133(78.2 \%)$ & $126(74.1 \%)$ & $44(25.9 \%)$ & $3.70(0.98)$ \\
\hline \multirow{3}{*}{$\begin{array}{l}\text { Region of origin } \\
\quad(n=1,587)\end{array}$} & Belgium & $291(36.2 \%)$ & $512(63.8 \%)$ & 547 (68.1\%) & $256(31.9 \%)$ & $3.74(0.95)$ \\
\hline & EU15 & $162(46.3 \%)$ & $188(53.7 \%)$ & $178(50.9 \%)$ & $172(49.1 \%)$ & $3.73(0.97)$ \\
\hline & Non-EU15 & $242(56.0 \%)$ & 190 (44.0\%) & $160(37.0 \%)$ & $272(63.0 \%)$ & $3.62(1.00)$ \\
\hline
\end{tabular}

${ }^{\mathrm{a}}$ Mean (SD). 
Table 4. Impact of generation and SES, controlled for gender, on educational tracks, delay in educational trajectory and expectations about the labour market only for participants with an EU15 migration background.

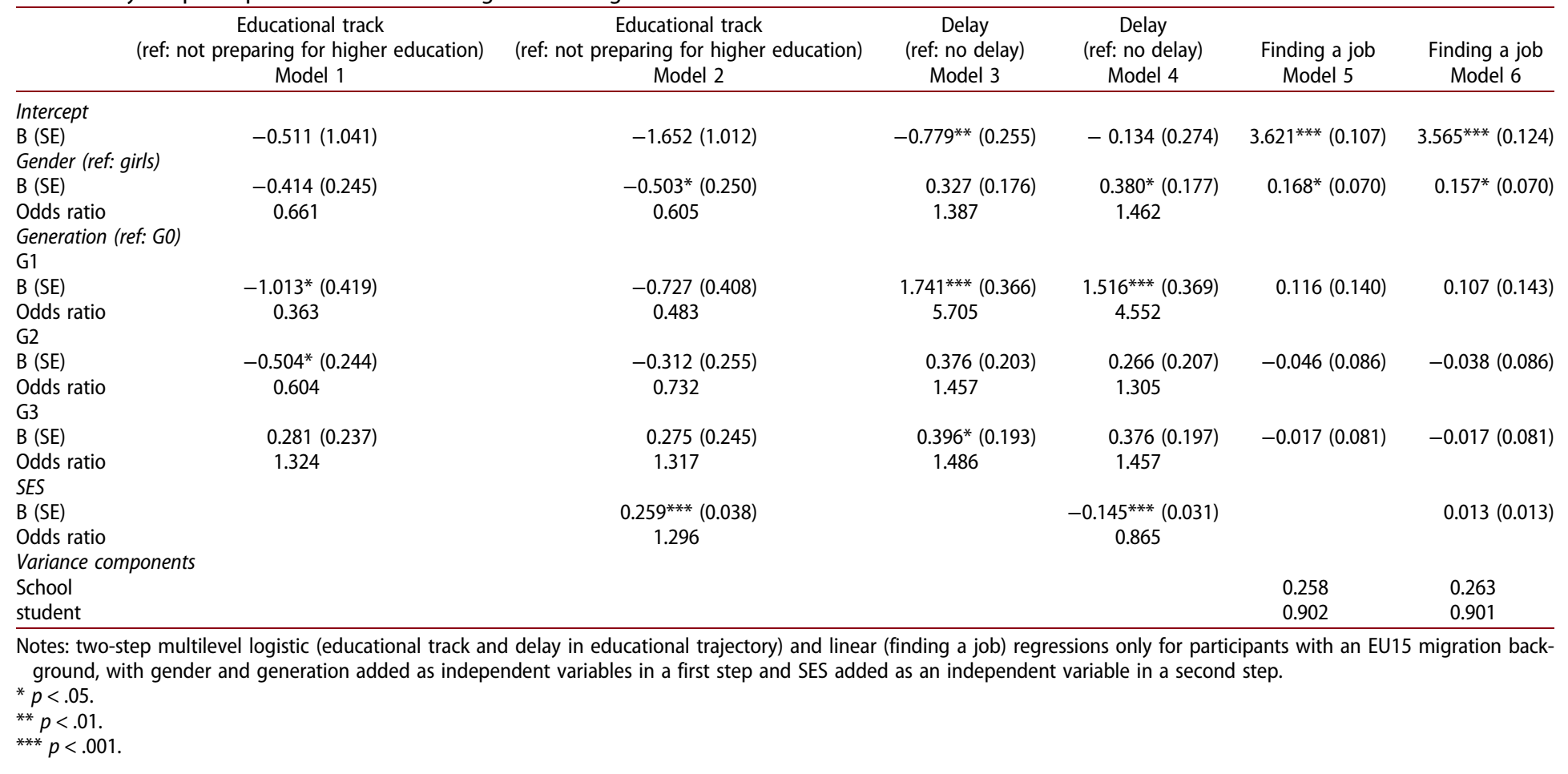


A lower SES background was associated with being in an educational track that did not prepare for higher education, with higher risks of having a delay in educational trajectory, but not with less certainty about finding a job quickly after graduating (Table 4, models 2, 4 and 6). This factor thus had an overall effect on the educational track youngsters were in and on the risks of having a delay in their trajectories (hypothesis 2). This effect might be an indication of schools being - often in rather unconscious ways mainly oriented towards middle-class children, thereby, amongst other elements, valuing these children's social capital more or showing higher expectations of them, factors that might explain these pupils' relative success in school. Further, entering SES in the model made all generational effects within the EU15 group disappear, except for the difference between G0 and G1 on the delay variable. Regarding the latter, the recent migration process might be influential. SES thus accounted for almost all differences between non-migrants and migrants with an EU15 background (hypothesis 2).

Exploring the differences between generations (hypothesis 1) within the non-EU15 group (hypothesis 3) (Table 5), participants from generations G1 and G2 had lower chances of being in an educational track that prepares them for higher education and showed higher risks of having a delay in educational trajectory compared to G0, but no significant difference between G3 and G0 was found (Table 5, models 1 and 3). For all migrant generations, there was a significant difference compared with $\mathrm{G} 0$ as regards finding a job quickly after graduation, which is a striking difference from the EU15 group (Table 5, model 5).

Similar to the EU15 group, a lower SES background was associated with being in an educational track that did not prepare for higher education, with higher risks of having a delay in educational trajectory, but not with less certainty about finding a job quickly after graduating (Table 5, models 2, 4 and 6). Also here, SES thus clearly impacted on the educational track youngsters were in and the risks of having a delay (hypothesis 2). However, in contrast to the EU15 group, when entering SES only the difference between G1 and G0 in expectations about finding a job disappeared, while all other differences persisted. SES is thus not the only factor explaining the differences between non-migrants and migrants with a non-EU15 background (hypothesis 2). One hypothesis here is that young people with a non-EU15 background are often visibly different from the EU15 and the majority population and also carry distinctive names, both elements evoking assumptions about their (different) ethnic, cultural or religious affiliation, and as such possibly inducing mechanisms of discrimination and institutional racism. This hypothesis is supported by the following results.

When asked for reasons why it would be hard to find a job, most of the youngsters with an EU15 migrant background referred to the current difficult 
Table 5. Impact of generation and SES, controlled for gender, on educational tracks, delay in educational trajectory and expectations about the labour market only for participants with a non-EU15 migration background.

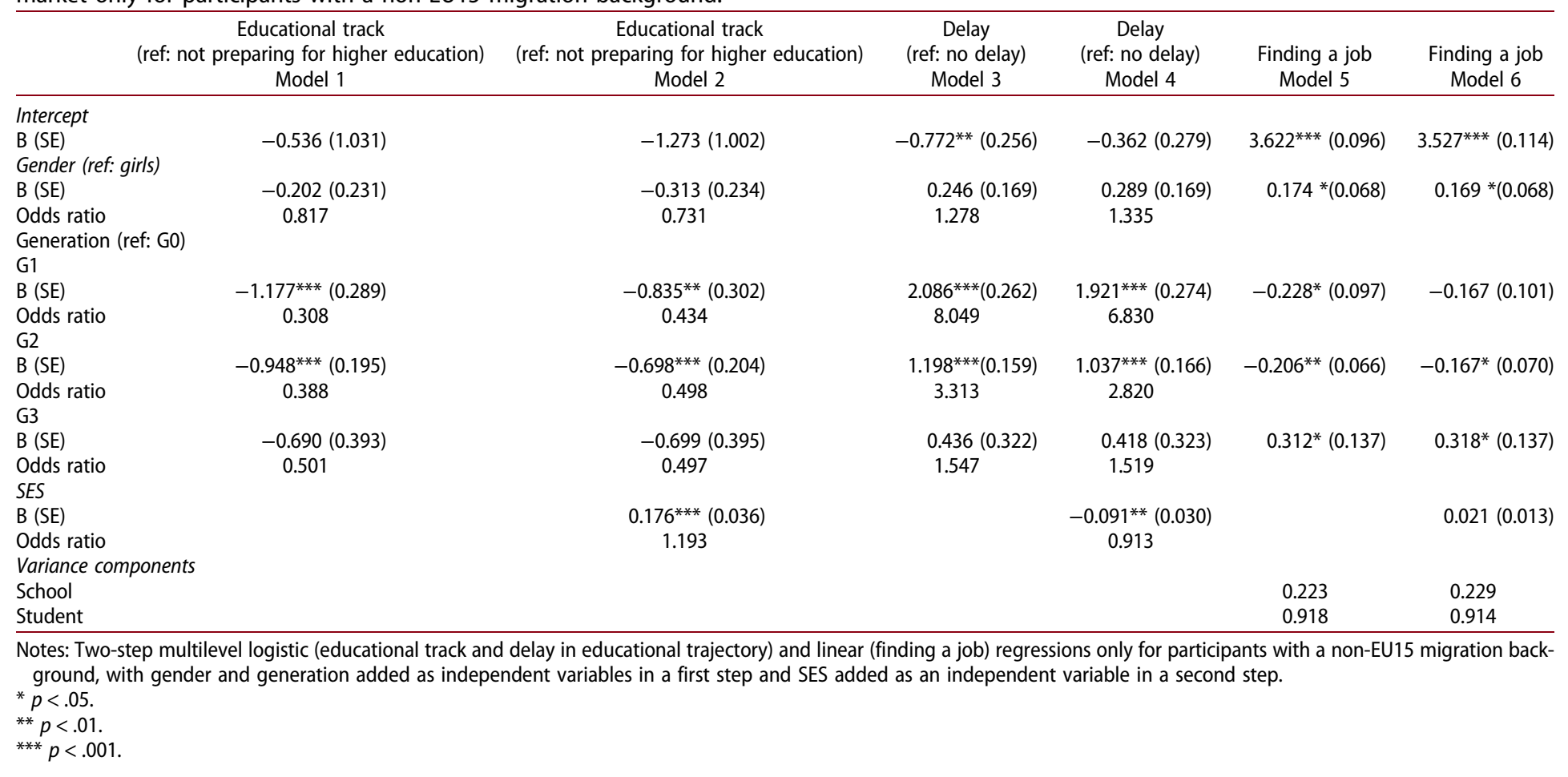


situation in the labour market, either by indicating the reason "There will not be any jobs for people with my diploma" (45 of 112 youngsters, 40.2 per cent) or by indicating "other" and explaining that the current economic crisis and high unemployment rates would make it difficult to find a job (30 or 26.8 per cent). Second, 20 or 17.9 per cent of the youngsters indicated "I will not be given a fair chance". The highest proportion of youngsters with a nonEU15 migrant background, on the other hand, indicated "I will not be given a fair chance" (60 of 166 youngsters, 36.1 per cent). The second and third most often indicated reasons were "There will not be any jobs for people with my diploma" (55 or 33.1 per cent) and "other", referring to the economic crisis and high unemployment rates (23 or 13.9 per cent). The young people's expectations, unfortunately, are supported by empirical evidence of discriminatory practices against them in the labour market.

\section{Conclusion and discussion}

This article's main aim was to investigate whether differences between migrants and non-migrants in structural assimilation disappeared over generations. Additionally, we wanted to see whether SES background could entirely explain differences between generations. Finally, we examined whether structural assimilation processes evolved more slowly for non-EU15 than for EU15 migrants.

The results for differences between generations of migrant adolescents in their educational tracks can be regarded as evidence supporting the traditional assimilation hypothesis. Indeed, we found a significant difference between the first and second generations of migrant adolescents and nonmigrants, but not between the latter and third-generation migrants. As indicated above, previous research has shown that there is progress towards more equal chances from first- to second-generation migrants in educational attainment, but that the gap with the majority population persists (Fincke 2008; Phalet and Swyngedouw 2003). Our study reveals that in the specific context of the two selected cities in Flanders, this gap does disappear for third-generation migrant adolescents. In contrast, both the results for delay in educational trajectories and expectations about the labour market do not support traditional assimilation hypotheses, since we did not find significant changes over migrant generations or even a persisting inequality. For delay in educational trajectories, significant differences were found between nonmigrants, on the one hand, and first- and third-generation EU15 migrants and first- and second-generation non-EU15 migrants, on the other. Regarding labour market expectations, significant differences were noted between nonEU15 migrants of all generations and non-migrants. For the first generation of migrant adolescents, the disadvantages could partly be explained by the fact that "the process of migration itself is disruptive" (Heath, Rothon, and Kilpi 
$2008,212)$, for example, because of issues with the recognition of foreign certificates and knowledge of the language (Heath, Rothon, and Kilpi 2008). Yet, despite the second and third generations of migrant adolescents being born and raised in Belgium, still they do not seem to have equal chances, compared to non-migrants. Apparently, having at least one (grand)parent born in another country creates obstacles to fully participating in educational structures and/or leads to people expecting more problems when entering the labour market. We can therefore conclude that there is no "straight-line assimilation" (Alba and Nee 1997) through which differences neatly disappear over generations.

Having a lower SES seems to decrease young people's chances of entering educational tracks preparing for higher education and to increase the risk of experiencing a delay in their educational trajectory, as was expected from our literature review (Breen and Jonsson 2005). Within the EU15 group, SES could explain almost all differences between migrants and non-migrants (except some aspects for the first generations). In contrast, within the non-EU15 group, the generational effects that were significant before entering SES into the model remained (Heath, Rothon, and Kilpi 2008). In this non-EU15 group, SES thus cannot sufficiently explain differences between the groups, and it is clear that other mechanisms are at stake here.

The remarkable differences between the EU15 group and the non-EU15 group may indicate that discrimination on the basis of ethnic-cultural origin plays an important role here. The non-EU15 group, many with roots in Turkey and Morocco, are not only often "visibly different" (Colic-Peisker and Tilbury 2007), but also often have distinctive names, which may induce assumptions about their ethnic origin and/or religious affiliation (Silberman, Alba, and Fournier 2007). Although we could conceptualize their pathways as (at risk of) downward assimilation (Portes and Zhou 1993), we will use this terminology carefully, since it might label this group even more as a problematic minority, giving rise to racist ideas and actions rather than to scrutinizing the ways in which educational systems and labour market mechanisms are unfair to some groups in society, and to taking action to assure equal opportunities for everyone (Alba, Kasinitz, and Waters 2011). Research has shown extensively how people who are (seen as) Muslims, which in Belgium often comes down to people of Moroccan or Turkish descent, have to cope with very negative attitudes towards them (Zemni 2011). While their socio-economic problems are often related to their perceived ethnic, cultural and/or religious affiliations (Zemni 2011), seldom are reflections made about the fact that some responsibility might also lie with the majority population and that adjusting the context might help significantly (Meuleman and Billiet 2003; Zemni 2011). The same mechanisms seem to be at work in schools: teachers and school principals acknowledge that youngsters with a migration background are more often oriented towards non-general 
educational trajectories and that this is problematic (Clycq et al. 2014). Yet, they attribute this mechanism mainly to language difficulties and the unwillingness of the youngsters and their families to adjust. No barriers are seen in the structural conditions of the Flemish educational system (Clycq et al. 2014). Remarkably, this discourse is often repeated in the narratives of the young migrants and their families, in which they seem to agree with the prevailing view of the impact of individual and family-related factors on school success or failure without mentioning more structural factors, despite the fact that they are often confronted with discriminatory remarks or attitudes, both within and outside school (Clycq et al. 2014). Radtke (2004) argues that the "choices" made by school staff about the educational trajectories of adolescents with a migration background are not so much deeply conscious choices on the basis of nationality or origin, but rather "things that happen" because of an internal, routine, unquestioned logic, combined with a rather unconscious idea of what "being a pupil" entails. He argues that these processes have to be analysed as cases of structural or institutional racism, as racism that forms an inherent part of structures and "the way things are done" (Vaught and Castagno 2008). This relates to the idea that institutions such as school and the way (entry into) the labour market functions are tailored towards a "white middle class", rendering the socio-cultural capital of (the children of) migrants not always "usable" within these often unquestioned - institutional logics (Clycq et al. 2014; Vaught and Castagno 2008).

Research has indeed shown that visible differences and names that evoke assumptions about someone's ethnic origin and/or religious affiliation (in Belgium concerning, in particular, people of Turkish and Moroccan descent) do make a (negative) difference in the labour market (Corluy et al. 2015; Silberman, Alba, and Fournier 2007). Youngsters with a non-EU15 migration background - hearing about and seeing the difficulties encountered by members of their social networks - may incorporate these observations and adjust their expectations accordingly (Van Praag 2013). This might also be a hypothesis that explains the differences in educational tracks (Van Praag 2013).

If policy and practice are to progress towards more equal opportunities, there is a large need to increase awareness of unquestioned institutional logics and the creation of spaces in which asking questions is possible. Further, awareness of the negative consequences attached to being visibly different is pivotal, combined with regulations to combat discrimination in the labour market.

It would be interesting to broaden this research with a larger sample, in order to further refine distinctions concerning origin (e.g. Eastern European youngsters as a separate group, given that they are less "visibly different" (Colic-Peisker and Tilbury 2007; Van Praag 2013)) and migration history. The 
latter is important because research shows that young people's migration history may impact on the frames of reference they have about education, the resources in their network they can rely on, and the educational choices they make (Van Praag 2013). While SES, generation and region of origin and the discriminatory processes that come along with those factors clearly play a very important role, other factors are also important. Fleischmann et al. (2012), for example, showed that for migrants, there is a positive correlation between the presence of co-ethnics in the neighbourhood and the chances of completing secondary education. This shows that factors on a school and neighbourhood level need to be explored in greater depth. Turning back to the broader assimilation theory and looking at the different dimensions of assimilation, we also need to explore further how the structural disadvantages and, in particular, the range of structural assimilation pathways for groups of different origins are linked to the other dimensions of assimilation (social, identity-related and cultural) (Brubaker 2001): do we also find different pathways in these dimensions, and do these particular pathways impede certain processes and/or accelerate others? Further quantitative and qualitative research could yield useful insights into the mechanisms at work here.

\section{Disclosure statement}

No potential conflict of interest was reported by the authors.

\section{References}

Alba, R., P. Kasinitz, and M. C. Waters. 2011. "The Kids Are (Mostly) Alright: SecondGeneration Assimilation Comments on Haller, Portes and Lynch." Social Forces 89 (3): 763-773. doi:10.1353/sof.2011.0024.

Alba, Richard, and V. Nee. 1997. "Rethinking Assimilation Theory for a New Era of Immigration." International Migration Review 31 (4): 826-874. doi:10.2307/2547416.

Blommaert, Jan, and Jef Verschueren. 1991. "The Pragmatics of Minority Politics in Belgium." Language in Society 20 (4): 503-531. doi:10.1017/S0047404500016705.

Boone, Simon, and Mieke Van Houtte. 2013. "Why are Teacher Recommendations at the Transition from Primary to Secondary Education Socially Biased? A MixedMethods Research." British Journal of Sociology of Education 34 (1): 20-38. doi:10. 1080/01425692.2012.704720.

Bouverne-De Bie, M., T. Van de Walle, and L. Bradt. 2014. "Bij wie kunnen jongeren terecht? Over informele steun en toegankelijkheid van sociale voorzieningen." In Jongeren in cijfers en letters. Bevindingen uit de JOP-monitor 3 en de JOP-schoolmonitor 2013, edited by L. Bradt, S. Pleysier, J. Put, J. Siongers, and B. Spruyt, 91-110. Leuven: Acco.

Breen, Richard, and Jan O. Jonsson. 2005. "Inequality of Opportunity in Comparative Perspective: Recent Research on Educational Attainment and Social Mobility." Annual Review of Sociology 31: 223-243. doi:10.1146/annurev.soc.31.041304.122232. 
Brubaker, R. 2001. "The Return of Assimilation? Changing Perspectives on Immigration and Its Sequels in France, Germany and the United States." Ethnic and Racial Studies 24 (4): 531-548. doi:10.1080/01419870120049770.

Cheung, Sin Yi. 2014. "Ethno-Religious Minorities and Labour Market Integration: Generational Advancement or Decline?" Ethnic and Racial Studies 37 (1): 140-160. doi:10.1080/01419870.2013.808757.

Clycq, Noel, Christiane Timmerman, Piet Van Avermaet, Johan Wets, and Philip Hermans, eds. 2014. Oprit 14. Naar een schooltraject zonder snelheidsbeperkingen. Gent: Academia Press.

Colic-Peisker, Val, and Farida Tilbury. 2007. "Integration into the Australian Labour Market: The Experience of Three "Visibly Different" Groups of Recently Arrived Refugees." International Migration 45 (1): 59-85. doi:10.1111/j.1468-2435.2007. 00396.x.

Corluy, V., J. Haemels, I. Marx, and G. Verbist. 2015. The Labour Market Position of Second-Generation Immigrants in Belgium. Brussels: National Bank of Belgium.

European Union. 1995-2015. “Eu Member Countries.” http://europa.eu/about-eu/ countries/member-countries/.

Fincke, Gunilla. 2008. Abgehängt, Chancenlos, Unwillig? Eine empirische Reorientierung von Integrationstheorien zu MigrantInnen der zweiten Generation in Deutschland. Berlin: Freie Universität Berlin.

Fleischmann, Fenella, Karen Phalet, Patrick Deboosere, and Karel Neels. 2012. "Comparing Concepts of Ethnicity in Ethnic Composition Measures: Local Community Contexts and the Educational Attainment of the Second Generation in Belgium." Journal of Ethnic and Migration Studies 38 (10): 1513-1531. doi:10. 1080/1369183x.2012.711033.

Heath, A. F., C. Rothon, and E. Kilpi. 2008. "The Second Generation in Western Europe: Education, Unemployment, and Occupational Attainment." Annual Review of Sociology 34: 211. doi:10.1146/annurev.soc.34.040507.134728.

Hox, Joop J. 2010. Multilevel Analysis. Techniques and Applications. 2nd ed. New York: Routledge.

International Labour Organization. 2012. International Standard Classification of Occupations - ISCO-08. Geneva: International Labour Office.

Jacobs, Dirk, Andrea Rea, Céline Teney, Louise Callier, and Sandrine Lothaire. 2009. De sociale lift blijft steken. De prestaties van allochtone leerlingen in de Vlaamse Gemeenschap en de Franse Gemeenschap. Brussel: Koning Boudewijnstichting.

Kao, G., and S. Thompson. 2003. "Racial and Ethnic Stratification in Educational Achievement and Attainment." Annual Review of Sociology 29: 417-442. doi:10. 1146/annurev.soc.29.010202.100019.

"Lokale Inburgerings- en Integratiemonitor 2013. Sint-Niklaas." 2013. Brussel: Agentschap voor Binnenlands Bestuur. Studiedienst van de Vlaamse Gemeenschap.

Meuleman, Bart, and Jaak Billiet. 2003. "De houding van Vlamingen tegenover 'oude' en 'nieuwe' migranten: diffuus of specifiek?." In Vlaanderen gepeild!, edited by APS, 137-176. Brussel: Ministerie van de Vlaamse Gemeenschap.

Park, R. E., and E. Burgess. 1969. Introduction to the Science of Sociology. Chicago, IL: University of Chicago Press.

Phalet, Karen, and Marc Swyngedouw. 2003. "Measuring Immigrant Integration: The Case of Belgium." Migration Studies 152: 773-803.

Portes, Alejandro, P. Fernández-Kelly, and W. J. Haller. 2005. "Segmented Assimilation on the Ground: The New Second Generation in Early Adulthood." Ethnic and Racial Studies 28 (6): 1000-1040. doi:10.1080/01419870500224117. 
Portes, Alejandro, and M. Zhou. 1993. "The New Second Generation: Segmented Assimilation and Its Variants." Annals of the American Academy of Political and Social Sciences 530: 74-96. doi:10.1177/0002716293530001006.

Radtke, Frank-Olaf. 2004. "Die Illusion der Merokratische Schule. Lokale Konstellationen der Produktion von Ungleichheit im Erziehungssystem." IMIS-Beiträge 200423 : 143-178.

Sierens, S. 2006. "Immigratiesamenleving, Onderwijs En Overheid in Vlaanderen: Een Gespannen Driehoeksverhouding." In Onderwijs Onderweg in De Immigratiesamenleving, edited by S. Sierens, M. Van Houtte, P. Loobuyck, K. Delrue, and K. Pelleriaux, 9-32. Gent: Academia Press.

Silberman, R., R. Alba, and I. Fournier. 2007. "Segmented Assimilation in France? Discrimination in the Labour Market Against the Second Generation." Ethnic and Racial Studies 30 (1): 1-27. doi:10.1080/01419870601006488.

Van Praag, Lore. 2013. "Frames of Reference for Comparison of Eastern European, Turkish, and North African Immigrants in Belgium." In Right on Track? An Explorative Study of Ethnic Minorities' Success in Flemish Secondary Education, 134151. Ghent: Ghent University.

Vanduynslager, Lieselot, Johan Wets, Jo Noppe, and Gerlinde Doyen. 2013. Vlaamse Migratie- en Integratiemonitor 2013. Antwerpen, Brussel: Steunpunt Inburgering en Integratie, Studiedienst van de Vlaamse Regering.

Vantieghem, W., H. Vermeersch, and M. Van Houtte. 2014. "Why "Gender" Disappeared from the Gender Gap: (Re-)Introducing Gender Identity Theory to Educational Gender Gap Research." Social Psychology of Education 17 (3): 357-381. doi:10. 1007/s11218-014-9248-8.

Vaught, Sabina E., and Angelina E. Castagno. 2008. "“I don't think I'm a Racist": Critical Race Theory, Teacher Attitudes, and Structural Racism." Race Ethnicity and Education 11 (2): 95-113. doi:10.1080/13613320802110217.

Vlaams Economisch Sociaal Overlegcomité. 2014. Advies monitoren van personen van allochtone afkomst op basis van administratieve databanken. Brussel: Commissie Diversiteit.

Zemni, S. 2011. "The Shaping of Islam and Islamophobia in Belgium." Race \& Class 53 (1): 28-44. doi:10.1177/0306396811406781. 